\title{
Analysis of American Potential Benefits At the Back of "Considerable" Sino-American Trade Deficit
}

\author{
Peng Luo \\ College of Economics \& Management, Dalian University \\ Dalian 116622, China
}

Tel: 86-411-8740-2730Ｅ-mail: pengluo@126.com

\begin{abstract}
The paper investigates reasons why there are large gaps in foreign trade statistics between China and America. Different statistic calibers, neglect of transit trade and transit added value, processing trade and industry transference, American increased direct investments in China, American multinational companies' operation in China and the adoption of export control policy to China have done great deal in this. Through analysis, finally we find that US has obtained great benefits at the back of trade deficits. It has become a powerful weapon to open Chinese market.
\end{abstract}

Keywords: Trade deficit, Processing trade, Export control policy

\section{Introduction}

The problem of unbalanced Sino-America trade has aroused extensive world attention recently. According to Chinese statistics, the US trade deficit to China begins from 1993 with 6.3 billion US dollars. In 2007, that amount reaches 163.3 billion US dollars. Till the first seven months of 2008, that amount has already reaches 91.7 billion US dollars. But according to the US statistics, US trade deficit to China begins from 1983 with a 0.3 billion US dollars. In 2007, the amount is 256.3 US dollars and in the first seven months of 2008, the amount is 142.3 billion US dollars. (See table 1) In 2000, China has become the largest trade deficit country with US instead of Japan and is the largest origin of American trade deficit.

Data resource: Chinese data comes from Ministry of Commerce of PRC, http://www.mofcom.gov.cn; American data comes from Ministry of Commerce of USA, http://www.census.gov

Statistic differences between two countries are to be found a normal phenomenon if view the present situation and history of economy and trade of every two countries. But such large statistic gaps between China and America are seldom seen. What is the reason? Has America really lost great deal of benefits in Sino-American trade? How shall we relieve the unbalanced contradiction of Sino-American trade?

\section{To view the problem of unbalanced Sino-American trade objectively}

\subsection{There are statistic caliber differences between China and America}

2.1.1 In statistic principle and method, China uses CIF price to calculate total volume of import goods and FOB price for export while America uses Customs value, which is the value according to the market price of export country estimated by US Customs, to calculate the total volume of import goods and FAS price for export. The export volume in FAS price is about 7\% lower than that in FOB price due to the delivery charges from dock to ship. In this way, America reduces the export and enlarges the import volume to a certain extent.

2.1.2 In statistic scope, America uses overall trade system and frontier is the statistic boundary by which the goods imported into America and stored in free trade zone and bonded warehouse are to be listed while China adopts specialized trade system using Customs boundary as statistic boundary and the goods stored in the bonded warehouse are not to be listed. This brings about the result of larger American statistic scopes than China and increases the US trade deficits.

2.1.3 America carries out its trade statistic according to origin principle which means the nation of goods is justified by the original producing place, which is the manufacturing place, producing place or processing place where substantial changes take place. But till now, there aren't any uniform implementing rules around the world. The American methods in confirming the origin of goods lead to statistic differences on both sides.

\subsection{America neglects transit trade and transit added value}

\subsubsection{About import}

In American statistics, the import value is over-estimated because of the neglect of transit trade and transit added value. 
A very large part of Sino-American trade is transit trade via the third party. According to Chinese statistics, $60 \%$ of Chinese export to America is transported via Hong Kong and other countries or regions. But according to analysis of American statistics, only $20 \%$ of Chinese goods are delivered to America directly; the other $80 \%$ is transported through the third party. The added value of goods in the third party after leaving China obviously can not be listed as Chinese export. The conclusion made by US-China Joint Commission on Commerce and Trade is that the average appreciation rate of goods exported from China mainland to America via Hong Kong is as high as $40.7 \%$ which is much higher than that in usual circumstances and the appreciation rates of some major transit goods such as toys and clothes even reach and beyond $100 \%$.

\subsubsection{About export}

In American statistics, the export value is under-estimated because of the neglect of transit trade. According to the analysis of expert of US-China Joint Commission on Commerce and Trade, in US export statistics, the transit trade via HK accounts for about a quarter of HK's statistics.

\subsection{Processing trade and industry transference play an important role}

Chinese trade surplus mainly comes from processing trade and the major section of export is from foreign-funded enterprises. Processing trade is one of the most important factors in the increasing process of Chinese export trade and has reaches as high as $70 \%$ of total export volume to America. The actual service income China gets finally accounts for only a small percentage if deduct the material cost and delivery management fee. It apparently does not tally with the realities if the final import price from China is viewed as entire export to America.

One of the reasons why Chinese processing trade develops so fast is that countries or regions like USA, Japan, HK and Taiwan adopt the industry transfer policy in order to reduce the producing cost. Along with the transfer of labor-intensive industry of Asia-Pacific countries and regions to China, China has increasingly turned into the principle manufacture base of labor-intensive products and has accordingly occupied dominant position in Chinese export product structure. In the past 20 years or so, countries and regions as Japan, Korea, HK, Taiwan, Singapore and others have always been the primary suppliers of American labor-intensive products. Now China is accepting the industry transferred from these countries and regions and at the same time inherits their shares of American market to a large extent. According to the data announced publicly by USA Department of Commerce, American trade deficit with China has been sharply increased from 2.8 billion US dollars in 1987 to 33.8 billion US dollars in 1995, but synchronous deficit to Korea, Singapore and Taiwan dropped from 34 billion US dollars to 7.8 billion US dollars.

\subsection{American enterprises increase their direct investments in China}

In face of fierce international competition, more and more American multinational corporations are regarding China as their export terrace. Among the American top 500 enterprises, there have been already over 400 which invest directly in China. These include major industries as machinery, metal, oil, electron, communication, chemistry, textile, light industry, food, agriculture, medicine, finance, insurance etc. Most of those already-ingoing enterprises are of import substitution type with a primary investing purpose of occupying Chinese market. Bearing such strong characters of import substitution, the investments of these enterprises are doomed to reduce Chinese import from America which leads to large Sino-American trade deficits.

\subsection{A large part of Chinese export to America comes from American companies operated in China}

America carries out optimal allocation system of production factors around the world by transferring those production and manufacturing links of low added value to China with a purpose of taking advantages of Chinese cheap labors in processing and then re-import to America. Statistics show that over half of the increased volumes of Sino-American trade are achieved by American enterprises located in China, many of whom are members of American manufacture association. Dell computer, Wal-mart, Motorola and Texas Instruments Company are all the leading export companies to America and Wal-mart itself accounts for over one seventh of Chinese total export volume to America.

\subsection{America adopts export control to China}

For the past many years, America adopted discriminatory export control policy to China which is the principle barrier restricting American export to China. It has exerted profound influences on bilateral trade. American Export Control Regulations divides all countries (except Canada) into 7 groups. From strict to loose, they are Z, S, Y, W, Q, T and V-group accordingly. China was listed in Y-group in 1949 when the new state was established. After the Korean War broke out, the US Commerce Department listed China in Z-group which meant totally prohibitive. Along with the recovery of Sino-American foreign relations in 1979, the American government released the technology restrictions to China and set up a P-group for China exclusively in 1980 in order to show difference with the former Soviet Union. In 1983, Reagan-administration downgraded China to V-group again. But in American policy making and implementation, there are still many discriminatory regulations which do not let China enjoy the real treatment of V-group countries. The Sino-American relationship came into dismal state after June 1989. American government stopped the discussion 
of releasing export control policy to China. Since 1990s the American government made a new series of sanction arrangements to China which included many export control items and made Sino-American economic and trade relationship suffered serious consequences. Especially after George W. Bush came into power, facing the daily-increasing trade deficit with China, the government adopted a much more strict policy restricting American high-tech products exported to China. Since then new changes have taken place in Sino-American balanced trade relationship and American trade surplus have changed into deficit step by step. A research made by international economy research institute in Washington shows that US loses export opportunities of as much as 3.5 to 13.5 billion US dollars to China every year due to export control policy in Chinese market.

\section{American benefits at the back of trade deficits}

\subsection{Analysis on American benefits among the trade deficits from the point of Sino-US import-export product structure}

Sino-American trade deficit is virtually a kind of compensatory trade deficit. From the imported commodities point of view, America mainly imports labor-intensive commodities as textiles, clothes, shoes, toys and household appliance etc. from China which reflects Chinese competitive advantages of labor-intensive commodities in international market. Recently Chinese high-tech products export volume has been increasing, but the processing is the main method and accounts for more than $90 \%$ with only less than $10 \%$ in ordinary trade method.

\subsubsection{Be good to the adjustment of American economic structure}

Most of Chinese commodities exported to America come from those industries in which no commodities are produced in America. Chinese labor-intensive export products to America do not affect American industrial production and employment and do not scramble for the international market share of American products as well. It is a kind of beneficial supplement to American economic structure and is good to the adjustment of American economic structure.

3.1.2 These cheap imported commodities not only satisfy the domestic demands but also are good to restraining inflation. Chinese products are both cheap in price and of high quality which are helpful in restraining American inflation and can bring substantial benefits to numerous consumers. If imported from other countries, American consumers will spend 20 billion US dollars more for the commodities as clothes, shoes, toys and electrical appliance etc. At the same time, America mainly exports high-tech and monopolistic products and China mainly exports products with low added value. According to the principle of international price scissors, considerable profits flow into America.

3.1.3 The entering of Chinese cheap products in large quantities into America causes American consumers to save large amount expenditure to deposit or invest and this plays an active role in US economic development.

\subsection{Reconsider American trade deficit combining the benefits of distribution patterns of international division of labor}

3.2.1 China, with rapid development of economy, has become an important resource of increased benefits of many multinational enterprises. Many American multinational enterprises have realized that, in order to keep competitive station they must grasp the opportunities of Chinese market. They adopt localization strategy and obtain large amount benefits in host countries by internal trade and price transference. Many of them, Motorola and Wal-mart, for example, have obtained abundant benefits thereout. Statistics show that in 2001, only 5\% of income of the 44 listed companies in America came from Chinese market. In 2006, that number has reached 108. Besides, an article in Wall Street Daily announced that in $2007,80 \%$ of American multinational companies in China being interviewed achieved profits while in 1998 nearly one third were in a state of deficit.

3.2.2 A majority of benefits of processing trade is obtained by American enterprises taking the low added value into consideration. Processing trade accounts for nearly $70 \%$ of total Sino-US trade. IPOD, mp3 player, the present starring product of Apple Corporation, is assembled in China. The price of the final finished product is about 265 US dollars. How is the benefit distributed? Chinese companies which assemble them get only about 4 US dollars in profit. The companies which design chip get about 5 US dollars and Apple Corporation gets 65 US dollars in profit. Because of Apple Corp.'s success, their stock price increased from 21 US dollars to 64 US dollars within last one year. In Sino-US trade statistics, American trade deficit is increased by 1.5 billion US dollars if "import" IPOD from China and this leads to an increase of 16 billion US dollars of American domestic wealth.

\subsection{Trade deficit has become a powerful weapon of America to open Chinese market}

As viewed from the situation of past few years, American government seldom required Chinese voluntary export restraints of certain commodities as what has been done with Japan. It put most of its focus on Chinese market access issues. Because America is a powerful service trading country with the largest service trade surplus, it wants to use surplus in service trade to offset deficit in goods trade and gain more benefits along with the opening of Chinese telecommunication and finance market. So America brings forward tough requirements in issues of Chinese service market opening.

Furthermore, US dollars obtained by China in high price have returned to America again in the form of buying American bond which equals to the discount loans from other countries. By the end of July 2008, the national debt of 
the United States hold by China has been up to as much as 518.7 billion US dollars and has become the second-largest holder of country. It plays an active role in developing US economy and balancing current account deficit.

\section{Countermeasures for dealing with unbalanced Sino-US trade}

\subsection{Adopt the right US trade strategy to promote the smooth development of trade between the two countries}

4.1.1 Taking "development, equality, mutual benefits" as the spirit to deal with bilateral economic and trade relations. "We should try our best to avoid the economic and trade issues politicized and bear in mind the long-term interests while dealing with bilateral trade issues," U.S. senior negotiators expressed the common desire of Sino-US economic and trade relations in the future through translation in a joint news conference.

4.1.2 Attach great importance to the role of US interest groups. In an open and pluralistic political framework of the United States, interest groups play a decisive role in US government's decision-making. For example, US government released restrictions on exports of computer standards twice in early 2002 and early 2003 . This was promoted by over 20 corporations including high-tech giants as Intel, Microsoft and IBM etc. Someone refers American interest groups as "the fourth component of the government". So we must strive for the support of friendly American interest groups.

4.1.3 Communicate positively and understand comprehensively. Promoting free trade accords with Sino-US fundamental and long-term interests. In September 2006, Chinese chairman Mr. Hujintao and American president Mr. Bush initiated mutually the establishment of Sino-US strategic economic dialogue. This is the highest ranking among the existing 20 consultation mechanisms. Till June 2008, China and US have been going on for four strategic economic dialogues with a focus on the long-term and strategic issues in the economic relations and have set up a framework for long-term and steady economic and trade development between the two countries. From this point of view, strategic economic dialogues play an irreplaceable role in promoting healthy development, preventing economic and trade frictions from being politicized and eliminating non-economic factors on the economic and trade barriers. Besides, China and US should actively develop roles of non-governmental organizations as Guild, Chamber of Commerce and so on, fully contact with the US interest groups and let them play a role of bridge and tie in Sino-US trade.

\subsection{Develop technology trade, promote US to release export control}

Sino-US trade has contents of both tangible and intangible trade among which technology transfer, the teaching of technology experience and management have the same features as service trade and the sales of technical equipments have the same features as tangible goods trade. Technology trade plays a greater role in Chinese industrial structure upgrade and is important to the balance of US trade deficit.

Technology trade is not only in favor of changing US trade deficit but also conducive to further improving and strengthening the Sino-US trade relations. This is a realistic way out of solving Sino-US trade deficit. In the process of establishing sound, transparent, cost-effective technology market, encouraging every country to carry out fine and open competition in technology export to China, US government will take into account their economic interests and market share which plays an important role in promoting US government to release dual-use technology exports to China.

\subsection{Promote the transformation and upgrading of processing trade, and enhance its contribution to China's economic} growth

At present, China's processing trade has become the main force of economic growth and has occupied half of the total import and export. In recent years, processing trade has been the major source of Chinese foreign trade surplus. In 2006, Chinese foreign trade surplus is 144.26 billion US dollars among which processing trade surplus accounts for $61.43 \%$. Chinese large trade surplus to US is mainly caused by processing trade.

For this reason, Chinese government should guide processing trade by policy measures in order to facilitate the realization of the industrial structure upgrade; improve and standardize the management of deep processing; work out relevant policies to support and guide enterprises to develop overseas processing trade; go high-tech and high added-value path to promote processing trade's contribution to the increase of national economy.

\subsection{Encourage enterprises to operate multinationally and support those qualified enterprises to invest in America directly}

The Government must make great efforts to support enterprises, especially industrial enterprises to invest directly in America and at the same time do a good job of macro-guidance in business consulting and information supply. This will not only avoid trade barriers, significantly reduce trade friction, but also be able to introduce advanced technology and management experiences more effectively and enhance the comprehensive international competitiveness of Chinese enterprises.

\section{Acknowledgement}

This research was supported by Canadian Center of Science and Education (B2008-121). 


\section{References}

Blustein \& Paul. (2004). U.S. cites China in complaint to WTO. Washington Post, No. 19, pp. 22-26.

Craig Elwell. (2006). The US trade deficit: cause, consequences and cures. World Economic Collection, No. 17, pp. 145-156.

Jacques Morisset. (2005). Unfair trade: empirical evidence in world commodity markets over the past 25 years. International Business, No. 4, pp. 97-107.

James Jackson. (2007). Foreign investment in US securities. CRS Report for Congress Order Code, No. 3, pp. 66-79.

Liu, Jianjiang. (2007) Inspiration from interaction of huge U.S. trade deficit with the industrial structure adjustment and low unemployment rate. Contemporary Finance, No. 17, pp. 72-75.

Mckinnon Ronald. (2007). The East Asian Dollar Standard. China Economic Review, No.7, pp. 35-38.

Michael Spence. (2007). We are all in it together (China and US economies). Wall Street Journal, No. 15, pp. 37-43.

$\mathrm{Mu}$, Liangping \& Zhang, Jingchun. (2006). Sino-US trade deficit with the United States changes of protection policy. International Economic Review, No. 9, pp. 48-51

Peter K. Yu. (2005). From pirates to partners (episode two): Protecting intellectual property in post-WTO China. Beijing: Machineary publishing corp. (Chapter 4).

Qi, Guanhua. (2008). Figures of Sino-US trade deficits were misleading: http://www.mofcom.gov.cn. (July 7, 2008).

Tang, Renwu. (2005). World economy integration. World Economic Collection, No. 15, pp. 477-485.

W. A. Lewis. (2007). World production, prices and trade. Manchester School of Economics and Social Science, No. 20, pp. 105-38.

Wang, Jian. (2004). Gold: Effect and countermeasures to dollarization. China Securities News, No. 38, pp. 295-302.

Wang, Li. (2007). Analysis of economic and trade relations between China and the United States in the first half of 2006. International Economic Cooperation, No. 11, pp. 34-37.

Wang, Ping. (2007). Rules of origin problems in processing trade. Economic Finance and Trade, No. 9, pp. 52-55.

Wang, Xuekun. (2008) The transition of China's foreign trade development strategy. Internatioinal Trade, No. 5, pp. 14-16.

Yin, Xiangshuo. (2006). Trade structure is more important: Unbalanced and asymmetric situation of Chinese dependence degree and import-export trade. Internatioinal Trade, No. 3, pp. 10-17.

Zeng, Ka. (2006). Complementary trade structure and U.S.-China negotiations over intellectual property rights. East Asia, No. 20, pp. 54-80.

Zhang, Luqing \& Wang, Li. (2005). Sino-US trade prospect effected by five hot items. International Business Daily, No. 12, pp. 129-136. 
Table 1. Mapping table of trade deficit statistics of China and America (billion US dollar)

\begin{tabular}{|c|c|c|c|c|c|c|c|}
\hline \multirow[t]{2}{*}{ year } & \multicolumn{3}{|c|}{ Chinese statistics } & \multicolumn{3}{|c|}{ American statistics } & \multirow[t]{2}{*}{ difference } \\
\hline & export & import & balance & export & import & balance & \\
\hline 1980 & 9.8 & 38.3 & -28.5 & 37.5 & 11.6 & 25.9 & 2.6 \\
\hline 1981 & 15.1 & 43.8 & -28.7 & 36 & 20.6 & 15.4 & 13.3 \\
\hline 1982 & 16.2 & 37.2 & -21 & 29.1 & 25 & 4.1 & 16.9 \\
\hline 1983 & 17 & 23.2 & -6.2 & 21.6 & 24.8 & -3.2 & 9.4 \\
\hline 1984 & 24.3 & 40.4 & -16.1 & 29.9 & 32.8 & -2.9 & 19 \\
\hline 1985 & 23.5 & 50.9 & -27.4 & 38 & 42.2 & -4.2 & 31.6 \\
\hline 1986 & 26.3 & 47.2 & -20.9 & 31.3 & 52.4 & -21.1 & 42 \\
\hline 1987 & 30.4 & 48.3 & -17.9 & 34.9 & 69.1 & -34.2 & 52.1 \\
\hline 1988 & 33.8 & 66.3 & -32.5 & 50.1 & 85.1 & -35 & 67.5 \\
\hline 1989 & 40.1 & 78.6 & -38.5 & 57.6 & 119.1 & -61.5 & 100 \\
\hline 1990 & 51.8 & 65.9 & -14.1 & 48.1 & 152.2 & -104.1 & 118.2 \\
\hline 1991 & 61.6 & 80.1 & -18.5 & 62.8 & 189.7 & -126.9 & 145.4 \\
\hline 1992 & 85.9 & 89 & -3.1 & 74.2 & 257.3 & -183.1 & 186.2 \\
\hline 1993 & 169.6 & 106.9 & 62.7 & 87.7 & 315.3 & -227.6 & 164.9 \\
\hline 1994 & 214.6 & 139.7 & 74.9 & 92.9 & 387.8 & -294.9 & 220 \\
\hline 1995 & 247.1 & 161.2 & 85.9 & 117.5 & 455.6 & -338.1 & 252.2 \\
\hline 1996 & 266.8 & 161.5 & 105.3 & 119.7 & 514.9 & -395.2 & 289.9 \\
\hline 1997 & 326.9 & 163 & 163.9 & 128 & 626 & -498 & 334.1 \\
\hline 1998 & 379.8 & 169.6 & 210.2 & 143 & 712 & -569 & 358.8 \\
\hline 1999 & 419.5 & 194.8 & 224.7 & 120 & 806 & -686 & 461.3 \\
\hline 2000 & 521 & 223.6 & 297.4 & 162.5 & 1000.6 & -838.1 & 540.7 \\
\hline 2001 & 542.8 & 262 & 280.8 & 192.3 & 1022.8 & -830.5 & 549.7 \\
\hline 2002 & 699.5 & 272.3 & 427.2 & 221 & 1252 & -1031 & 603.8 \\
\hline 2003 & 924.7 & 338.6 & 586.1 & 284 & 1524 & -1240 & 653.9 \\
\hline 2004 & 1249.5 & 446.8 & 802.7 & 347.2 & 1619.8 & -1272.6 & 446.8 \\
\hline 2005 & 1629 & 487.3 & 1141.7 & 418.4 & 2434.6 & -2016.2 & 874.5 \\
\hline 2006 & 2034.7 & 592.1 & 1442.6 & 552.2 & 2877.7 & -2325.5 & 882.9 \\
\hline 2007 & 2327 & 693.8 & 1633.2 & 652.4 & 3215.1 & -2562.7 & 929.5 \\
\hline 2008.1-7 & 1403.8 & 487.2 & 916.6 & 431.3 & 1854.7 & -1423.4 & 506.8 \\
\hline
\end{tabular}

